\title{
FENOMENA PERALIHAN GENDER PADA PENARI JATHIL DALAM KESENIAN REOG DI KABUPATEN PONOROGO
}

\author{
Wasrinda Kanni Adelita \\ Bintang Hanggoro Putra \\ Universitas Negeri Semarang \\ Email : wasrindaunnes@ymail.com \\ Bintanghanggoro@yahoo.co.id
}

\begin{abstract}
Abstrak
Fenomena peralihan gender sering terjadi di Indonesia khususnya dalam seni pertunjukan. Sebuah fenomena peralihan gender pada penari Jathil merupakan salah satu bentuk dari permasalahan yang sudah ada dalam kesenian Reog. Fenomena peralihan gender pada penari Jathil berawal dari adanya penari Jathil lakilaki yang disebut Gemblak yang bersikap feminim. Sikap tersebut dianggap tidak sejalan dalam kesenian Reog sehingga fenomena yang terjadi adalah penari Jathil laki-laki digantikan dengan penari Jathil perempuan. Dukungan dari gejala tersebut dengan diadakannya pertemuan yang membahas perubahan penari dan pembakuan dalam kesenian Reog. Pengaruh peralihan penari Jathil juga terlihat dari perubahan gerak dalam tarian yang sudah dibakukan, perubahan busana pada penari, dan perubahan musik. Penelitian ini diharapkan dapat memberi persepsi positif terhadap fenomena peralihan gender pada penari Jathil serta dapat mengapresiasi kembali kisah kesenian Reog

Kata kunci : Fenomena Peralihan Gender, Penari Jathil, Kesenian Reog, Gemblak
\end{abstract}

\section{PENDAHULUAN}

Kabupaten Ponorogo dikenal dengan sebutan Kota Reog atau Bumi Reog yang merupakan daerah asal dari kesenian Reog Ponorogo. Selain kesenian Reog, Ponorogo juga memiliki banyak kesenian, seperti kesenian Gajah-gajahan, kesenian Jaran Thik, kesenian Odrot dan kesenian Thekthur. Reog adalah sebuah kesenian budaya berbentuk teater yang dilakukan oleh sekelompok pemain drama tari dengan berbagai karakter dan perwatakan pelaku. Fenomena peralihan gender sering terjadi di Indonesia khususnya dalam seni pertunjukan. Sebuah fenomena peralihan gender pada penari Jathil merupakan salah satu bentuk dari permasalahan yang sudah ada dalam kesenian Reog. Banyak masyarakat yang kurang menerima fenomena peralihan ini dengan alasan hilangnya adat asli atau keaslian dari suatu kesenian khususnya kesenian Reog Ponorogo, dan juga banyak masyarakat yang menerima fenomena perubahan ini karena membawa dampak positif seiring dengan berkembangnya kesenian Reog Ponorogo yang ditampilkan dengan lebih kreatif dan inovatif. Fenomena dilihat dari segi antropologi menyebutkan bahwa fenomena adalah buah pikiran dan hati manusia. Pemikiran dan hati ini hanya akan dapat nampak dalam suatu tindakan. Tindakan inilah yang dapat dilihat sebagai fenomena yang jelas (Endraswara 2006:45).

Fenomena merupakan keadaan yang dapat diamati dan dinilai lewat kacamata ilmiah atau lewat disiplin ilmu tertentu. Fenomena Peralihan Gender pada Penari Jathil dalam Kesenian Reog di Kabupaten Ponorogo sangat mempengaruhi perubahan kehidupan masyarakat karena masyarakat masih sangat menjunjung tinggi adat kesenian Reog di Kabupaten Ponorogo. 
Konsep gender adalah sifat yang melekat pada kaum laki-laki dan perempuan yang dibentuk oleh faktorfaktor sosial maupun budaya, sehingga lahir beberapa anggapan tentang peran sosial budaya laki-laki dan perempuan. Bentukan sosial atas laki-laki dan perempuan itu antara lain: perempuan dikenal sebagai makhluk yang lemah lembut, keibuan, cantik, emosional, sedangkan laki-laki dianggap kuat, rasional, jantan, dan perkasa. Sifat-sifat di atas dapat dipertukarkan dan berubah dari waktu ke waktu (Handayani \& Sugiarti 2008:5). Gender tidak bersifat biologis melainkan dikontruksikan secara sosial. Gender tidak dibawa sejak lahir melainkan dipelajari melalui sosialisasi (Sunarto 2004:110). Gender sebagai konsep sosial yang membedakan (dalam arti: memilih atau memisahkan) peran antara laki-laki dan perempuan. Perbedaan fungsi dan peran antara laki-laki dan perempuan itu tidak ditentukan karena antara keduanya terdapat perbedaan biologis atau kodrat, tetapi dibedakan atau dipilah-pilah menurut kedudukan, fungsi dan peranan masing-masing dalam berbagai bidang kehidupan dan pembangunan (Handayani \& Sugiarti 2008:5). Gender bukanlah kodrat ataupun ketentuan Tuhan, oleh karena itu gender berkaitan dengan proses keyakinan bagaimana seharusnya laki-laki dan perempuan berperan dan bertindak sesuai dengan tata nilai yang terstruktur, ketentuan sosial dan budaya di tempat mereka berada. Gender adalah pembeda antara perempuan dan laki-laki dalam peran, fungsi, hak, perilaku, yang dibentuk oleh ketentuan sosial budaya setempat (Nugroho 2008:4).

Seni adalah bagian dari kehidupan manusia yang dapat mempengaruhi perkembangan jiwa manusia secara estetis (Sumaryanto 2000:138). "Seni" yang biasa disebut dengan "seni adiluhung" adalah jenis ungkapan seni yang mempunyai implikasi kepada renungan; didukung oleh teknik yang cukup rumit; ada perangkat konsep yang mendasarinya; sedangkan "hiburan" sifatnya langsung merangsang pancaindra atau juga tubuh untuk mengikuti dengan gerak; mementingkan sifat glamur dan sensasional (Sedyawati 2007: 130-131).

Tradisional adalah aksi dan tingkah laku yang keluar alamiah karena kebutuhan dari nenek moyang yang terdahulu. Tradisi adalah bagian dari tradisional namun bisa musnah karena ketidakmauan masyarakat untuk mengikuti tradisi tersebut (Wikipedia, Tanggal Download 29 Agustus 2016).

\section{METODE}

Metode penelitian yang digunakan dalam penelitian ini adalah metode kualitatif. Peneliti dalam menguraikan permasalahan menggunakan data kualitatif tentang Fenomena peralihan gender pada penari Jathil untuk diuraikan secara deskriptif. Data diperoleh melalui observasi, wawancara, dan dokumentasi. Secara umum data yang telah diperoleh dari penelitian dapat digunakan untuk memahami, memecahkan dan mengantisipasi masalah oleh karena itu, untuk dapat melakukan penelitian yang baik dan benar seorang peneliti perlu memperhatikan cara-cara penelitian atau lebih dikenal dengan metode penelitian yang sesuai dengan bidang yang diteliti, sehingga memperoleh hasil penelitian sesuai dengan apa yang diharapkan yaitu sesuai dengan kondisi yang ada di lapangan (Sugiyono 2015:2-3). Metode penelitian kualitatif sering disebut metode penelitian naturalistik karena penelitiannya dilakukan pada kondisi yang alamiah (natural setting) disebut juga sebagai model etnografi, karena pada awalnya metode ini lebih banyak digunakan untuk penelitian bidang antropologi budaya disebut sebagai metode kualitatif, karena data yang terkumpul dan analisisnya lebih bersifat kualitatif (Sugiyono 2015:8). Analisis data yang digunakan dalam penelitian ini menggunakan analisis data model interaktif yang dikemukakan oleh 
Sugiyono (2015:245) bahwa teknik Analisis data adalah sebuah proses yang sangat penting dilakukan dalam kegiatan penelitian, sebab analisis data yang tepat akan menghasilkan kesimpulan dan data yang tepat pula. Analisis data dalam penelitian kualitatif dilakukan sejak sebelum memasuki lapangan, selama di lapangan, dan setelah di lapangan. Analisis telah mulai sejak merumuskan dan menjelaskan masalah, sebelum terjun kelapangan, dan berlangsung terus sampai penulisan hasil penelitian. Analisis data menjadi pegangan bagi penelitian selanjutnya. Analisis data lebih difokuskan selama proses di lapangan bersamaan dengan pengumpulan data (Sugiyono 2015:245). Teknik uji keabsahan data dalam penelitian ini menggunakan triangulasi teknik. Sugiyono (2015:241) menyatakan bahwa triangulasi teknik untuk menguji kredibilitas data dengan cara mengecek data kepada sumber yang sama dengan teknik yang berbeda, misalnya data diperoleh dengan wawancara, lalu dicek dengan observasi, dokumentasi, atau kuesioner.

\section{HASIL DAN PEMBAHASAN}

Berdasarkan hasil penelitian dilapangan, fenomena peralihan gender pada penari Jathil dalam kesenian Reog.

\section{Fenomena Peralihan Gender pada Penari Jathil}

Fenomena peralihan gender pada penari Jathil muncul sebagai wujud kebudayaan dan cerita yang sangat dikenal masyarakat. Pada awalnya masyarakat menanggapi fenomena ini dari sudut berbeda, mereka mengganggap bahwa budaya yang ada di Ponorogo adalah budaya turun temurun dari nenek moyang sehingga perlu sekali dijaga karena masih percaya kepada leluhurnya. Masyarakat mendengar cerita serta legenda dan hanya melihat sedikit dari fenomena yang terjadi. Bertambahnya jaman membuat fenomena ini semakin terbuka dimata masyarakat, tidak hanya percaya pada hal-hal mistis saja, tetapi semua peristiwa dan fenomena dipelajari secara mendalam.

Fenomena peralihan gender pada penari Jathil berawal dari penari Jathil atau yang biasa disebut gemblak ini berubah menjadi feminim. Gemblak adalah salah seorang simpanan yang dimiliki oleh Warok. Penari Jathil laki-laki biasa disebut gemblak. Pemain jathilan biasanya diambil dari gemblak. Praktek gemblakan adalah suatu keadaan di mana warok memanfaatkan seorang gemblak untuk menemaninya dalam pementasan Reog maupun di luar pementasan Reog, bahkan gemblak juga diminta untuk melayani warok sebagai pemuas nafsu seksualitasnya. Dilihat dari peralihan ini secara umum penonton menggemari Jathil perempuan dari pada laki-laki. Selain itu, praktek gemblakan juga sudah banyak ditentang di kalangan masyarakat karena kemajuan jaman. Praktek gemblakan juga dianggap tidak sesuai dengan kepribadian bangsa dan tidak sejalan dengan kebudayaan Indonesia. Hal ini dikarenakan gemblak sering menghabiskan waktu ke dalam lingkup kesenian dan menari baik di dalam kesenian Reog maupun di luar kegiatan kesenian Reog, sehingga secara langsung terbawa sikapnya menjadi sosok yang feminim. Berubahnya sikap gemblak tersebut dan berubahnya jaman, maka masyarakat menganggap bahwa gemblak sudah tidak layak ada dalam kesenian Reog, karena semakin berubahnya jaman para penonton menganggap bahwa kesenian Reog lepas dari hal-hal ghaib dan sudah menganggap kesenian Reog berkembang secara modern serta mengikuti perkembangan jaman dengan menggunakan keahlian dan ilmu yang dipelajari. Salah satu hal tersebut menjadi fenomena yang terjadi pada jamannya sehingga perlu untuk digantikan menjadi penari perempuan.

Pada masa orde lama perkembangan seni Reog Ponorogo tidak memperoleh bimbingan serta fasilitas yang 
layak, sehingga perkumpulan Reog di desa-desa tidak terorganisir dengan baik. Hal tersebut berdampak buruk terhadap kesenian Reog, dan pada akhirnya terjadi persaingan antara kelompok Reog. Seiring berjalannya waktu pada tahun 1950 perkembangan kesenian Reog sudah terdengar sampai ke pemerintah daerah, tetapi memiliki fungsi yang berbeda, yaitu kesenian Reog menjadi sarana untuk kepentingan politik. Pada tahun 1966-1969 kesenian Reog mengalami kevakuman dan muncul kembali ditahun 1969.

Pada tahun 1977 Bupati Tingkat II Ponorogo H. Soemadi mengadakan pertemuan antar tokoh kesenian Reog. Mereka di kumpulkan oleh Bupati di rumah salah satu kepala desa (Imam Sukadi) yang dihadiri oleh 70 orang. Bupati meminta agar para tokoh dan anggotanya berkenan untuk membantu keamanan daerah Ponorogo, mengaktifkan dan menyatakan kembali Reog-reog yang ada. Pertemuan ini berlanjut membahas bagaimana peralihan Kesenian Reog supaya tertib dan dikelola dengan baik. Pertemuan itu juga membahas tentang peralihan penari Jathil dari penari laki-laki ke penari Jathil perempuan. Perubahan penting dalam pertunjukan Reog Ponorogo pada tahun 1980-an adalah pergantian penari Jathil dari laki-laki ke penari Jathil perempuan.

Fenomena peralihan gender pada penari Jathil juga bisa dilihat dari gerakan yang sudah dibakukan untuk sekarang. Gerakan dalam tari Jathil pada masa penari laki-laki disebut dengan jathil 80an. Setelah adanya peralihan penari Jathil menjadi perempuan maka dibakukan dan ditetapkan dengan sebutan Jathil 90-an. Jathil masa 80-an menggunakan gerakangerakan tidak baku dan banyak gerakan improvisasi antara lain gerakan berjalan jinjit dan memutar, keplok doro, colotan, edreg (gerak badan yang menggoda). Untuk gerakan yang sudah dibakukan dan terus dikembangkan hingga sekarang antara lain gerak berjalan jinjit dan memutar diganti dengan congklang, gerakan keplok doro diganti dengan kalangkinantang, sembahan, edreg diganti dengan obah bahu, jalan empat, tebahan, gejugan, ukel karno, lawung, penthangan tangan, dan srisik.

\section{Pengaruh Peralihan Gender pada Penari Jathil dalam Kesenian Reog}

Fenomena peralihan terjadi karena seleksi alam, jaman dahulu adanya gemblak karena memang berawal dari sejarah nenek moyang yang mana penari Jathil ditarikan oleh seorang laki-laki. Anak anak jaman dahulu tidak ada yang sekolah, karena memang belum banyak sekolahan yang berdiri. Kegiatan anakanak hanyalah bermain, menurut pemikiran orang tua, dari pada bermain dan menganggur lebih baik diopeni warok dan dilatih menari lalu dijadikan gemblak. Berjalannya waktu, sekolah dan pendidikan formal maupun nonformal sudah banyak, kegiatan kesenian sudah berkembang, lama kemudian gemblak semakin berkurang.

Peralihan penari Jathil juga berpengaruh terhadap anggapan yang timbul dari masyarakat. Pertunjukan kesenian Reog di dalamnya terdapat sebuah adegan di mana atraksi dilakukan oleh Singobarong dan Jathilan. Atraksi itu antara lain, seorang penari Jathil dipikul diatas kepala Singobarong, lalu penari Jathil tersebut menari-nari. Jaman dahulu ketika penari Jathil masih ditarikan oleh laki-laki, entah dipikul atau digendongpun tidak masalah karena sama-sama laki-laki, tapi karena sekarang penari Jathil sudah beralih dan ditarikan oleh perempuan, sedangkan sekarang dalam pertunjukan kesenian Reog masih terdapat atraksi seperti itu, maka banyak masyarkat yang berkomentar tidak baik.

Peralihan gender pada penari Jathil juga berpengaruh dengan kemistisan kesenian Reog. Pada jaman dahulu, barongan Reog sangat disakralkan dan 
disucikan, Barongan tersebut juga sering diberi sesaji, untuk sekarang sudah tidak lagi. Hal ini terjadi karena pada jaman dahulu tokoh dalam kesenian Reog sudah berumur dan dari kalangan orang tua sehingga, mereka masih mempercayai kekuatan dan keberadaan leluhur serta nenek moyang. Setelah kesenian Reog memasuki orde baru dan dibakukan, tokoh yang terlibat adalah pelajar, remaja dan anak-anak sehingga, untuk kesenian Reog pada jaman sekarang ini ditanamkan kepada seluruh masyarakat dan terutama pelaku kesenian Reog tidak ada hal-hal yang mengandung kemistisan atau ghaib, seluruh kegiatan pertunjukan kesenian Reog dilakukan dengan pemanasan, latihan murni dan kemampuan dari penari itu sendiri.

\section{SIMPULAN DAN SARAN}

Berdasarkan hasil dan pembahasan penelitian mengenai fenomena peralihan gender pada penari Jathil dari penari Jathil laki-laki ke penari Jathil perempuan dan pengaruh peralihan penari Jathil dalam kesenian Reog dapat disimpulkan bahwa fenomena peralihan gender pada penari Jathil dari penari laki-laki ke penari perempuan terjadi karena adanya gejala yang tampak pada penari jathil laki-laki yang sikap nya berubah menjadi feminim, hal ini membuat masyarakat beranggapan aneh sehingga mereka mengambil tindakan yaitu mengadakan pertemuan antar tokoh kesenian Reog di Kabupaten Ponorogo yang membahas pembakuan pada kesenian Reog dan Peralihan dari penari laki-laki dan penari Perempuan dan sudah ditetapkan langsung pada tahun 1977 oleh Bupati Tingkat II H. Soemadi. Pengaruh dari peralihan penari Jathil juga disebabkan oleh perubahan jaman. Masyarakat Ponorogo sudah menganggap praktek gemblakan tidak pantas lagi karena dianggap tidak sesuai dengan keadaan budaya masa sekarang.
Berdasarkan kesimpulan penelitian, maka penulis merekomendasikan berupa saran-saran sebagai berikut:

1. Bagi penari Jathil laki-laki fenomena peralihan gender bukanlah sesuatu yang dianggap aneh atau berbeda dengan yang lainnya. Tetapi fenomena ini adalah suatu kreativitas seorang penari dalam dunia seni tari dan berperan dalam memajukan perkembangan kesenian Reog pada jamannya.

2. Bagi para seniman Ponorogo diharapkan agar mengadakan kembali pertemuan secara rutin guna membahas kesenian khususnya kesenian Reog, karena kegiatan ini sangat penting agar kesenian Reog terus berkembang dan mengikuti kemajuan jaman.

3. Bagi masyarakat Ponorogo hendaknya memberikan persepsi positif terhadap fenomena peralihan gender pada penari Jathil serta dapat mengapresiasi kembali kisah kesenian Reog agar berguna bagi generasi penerus.

\section{DAFTAR PUSTAKA}

Endraswara, Suwardi. 2012. Metodologi Penelitian Kebudayaan. Yogyakarta: UGM Press.

Handayani T. \& Sugiarti. 2008. Konsep \& Teknik Penelitian Gender. Malang : UMM Press.

Nugroho, Riant. 2008. Gender dan Strategi Pengarus-Utamaannya Di Indonesia.Yogyakarta: Pustaka Pelajar.

Kamanto, Sunarto. 2004. Pengantar Sosiologi. Jakarta: Fakultas Ekonomi Universitas Indonesia.

Sedyawati, Edi. 2006. Budaya Indonesia: Kajian Arkeologi, Seni, dan 
Sejarah. Jakarta: Raja Grafindo Persada.

Ambarwangi, S., \& Suharto, S. (2014). REOG AS MEANS OF STUDENTS'

APPRECIATION AND

CREATION IN ARTS AND CULTURE BASED ON THE LOCAL WISDOM. Harmonia: Journal Of Arts Research And Education, 14(1), 37-45. doi:http://dx.doi.org/10.15294/ harmonia.v14i1.2789

Irianto, A. (2016). The Development of Jathilan Performance as an Adaptive Strategy Used by Javanese Farmers. Harmonia: Journal Of Arts Research And Education, 16(1), 38-48. doi:http://dx.doi.org/10.15294/ harmonia.v16i1.5213

Sumaryanto, Totok. 2007. Pendekatan Kuantitatif dan Kualitatif dalam Penelitian Pendidikan Seni. Semarang : Unnes Press.

Sugiyono. 2015. Metode Penelitian Kuantitatif, Kualitatif dan $R \& D$. Bandung : Alfabeta.

https://id.m.wikipedia.org/Wiki/Tradisi (Tanggal download 29 Agustus 2016) 